\title{
Design of Motor Current Signature Analysis (MCSA) Based on LabVIEW for Online Detection of Induction Motor Faults
}

\author{
Dimas Anton Asfani ${ }^{1,2}$, Soedibyo ${ }^{1}$, I Made Yulistya Negara ${ }^{1}$, Daniar Fahmi ${ }^{1}$, Muhammad Eko Septiawan ${ }^{1}$, \\ Mochammad Wahyudi ${ }^{1}$, and Neisya Islamey Rifma ${ }^{1}$ \\ ${ }^{1}$ Department of Electrical Engineering \\ Institut Teknologi Sepuluh Nopember (ITS) \\ Surabaya, Indonesia \\ ${ }^{2}$ Center of Excellence for Automotive Control \& System ITS \\ anton@ee.its.ac.id
}

\begin{abstract}
Induction motor is the most common used electric motor in industry. Along with its operation, induction motor can savere certain damage which is generally dominated by internal fault, such as s rotor fault, stator fault, and bearing fault. In this paper, the online detection based on motor current signature analyses (MCSA) for such faults was designed using LabVIEW. MCSA was performed to obtain the frequency which indicated the presence of certain damage of induction motor. The experimental result showed that the accuracy of proposed method reached $90 \%$.
\end{abstract}

Keywords-induction motor; online detection; rotor fault; stator fault; bearing fault; MCSA.

\section{INTRODUCTION}

Induction motor is one of the most widely used load in industry. This causes the production process of industry is highly depended on performance of induction motor. However, along with its operation, induction motor can experience certain fault which leads to decreased performance, such as decreased efficiency, and even fatal damage, such as induction motor is out of service.

There are many kinds of induction motor damage. However, as stated in [1], about $90 \%$ of induction motor damage cases is dominated by the internal faults. This internal fault can be a broken rotor, stator fault, and bearing fault.

The existance of faulty induction motor is very undesirable since it is accompanied by unscheduled stopped production process of industry. In the end, the industry will suffer a great economic losses [2]. This makes the fault detection for induction motor is highly needed in order to prevent further damage or minimize damage [3].

In this paper, fault detection for induction motor based on motor current signature analyses (MCSA) was designed. There were three artificial fault conditions given to the tested induction motor, that was stator fault, rotor fault, and bearing fault. By using MCSA, the characteristic of frequency spectrum would be discriminated between induction motor with normal condition, stator fault, rotor fault, and bearing fault.

\section{Motor CURRENT SignATURE ANALYSES (MCSA)}

MCSA is a method to determine the operation condition of induction motor without affecting its operation (online detection method). MCSA analyzes electrical signal containing current component. MCSA uses current spectrum of stator windings of induction motor to be further processed by using fast fourier transform (FFT). In FFT method, the signal is transformed from time domain to frequency domain. When certain fault occurs, current spectrum will change and be different from its normal condition (before the fault occurs). There are some faults which is able to be detected by using MCSA method, such as rotor fault, stator fault, bearing fault, and eccentricity [4].

\section{A. MCSA for Rotor Fault Detection}

Fault of rotor bar can be detected by its abnormal harmonics frequency as equation below [1]:

$$
f_{b r b}=(1 \pm 2 k s) f_{s}
$$

with $f_{b r b}$ is frequency which indicates rotor fault, $k$ is integer constants, $s$ is slip in per unit $(\mathrm{pu})$, and $f_{s}$ is fundamental freuency of power supply.

\section{B. MCSA for Stator Fault Detection}

The frequency which indicates stator fault can be calculated by using equation below:

$$
f_{\text {stator }}=\left[\frac{n}{p}(1-s) \pm k\right] f_{s}
$$

with $f_{\text {stator }}$ is frequency which indicates stator fault, $n$ is integer, $k$ is integer constants, $s$ is slip in per unit (pu), and $f_{s}$ is fundamental freuency of power supply. 


\section{MCSA for Bearing Fault Detection}

The presence of bearing fault on induction motor can be detected by its abnormal harmonics frequency as below [5]:

$$
\begin{aligned}
& f_{\text {outer.bearing }}=[0.4 n(1-s)] f_{s} \\
& f_{\text {broken.bearing }}=\left|f_{s} \pm k f_{\text {outer.bearing }}\right|
\end{aligned}
$$

with $f_{\text {broken bearing }}$ is frequency which indicates bearing fault, $n$ is integer, $k$ is integer constants, $s$ is slip in per unit (pu), and $f_{s}$ is fundamental freuency of power supply.

\section{EXPERIMENTAL SETUP}

\section{A. System Configuration}

This experiment used starting current analyses in squirrel cage motor induction based on MCSA method. It involved synchronous generator, multiple lamps, tachometer, analog to digital converter module consisted of cDAQ-9171 and NI 9215, keys, hammer and pliers. Fig. 1 depicted induction motor damage detection system for this experiment.

The experiment used two three-phase induction motor with different rated power, that was $2 \mathrm{HP}(1.492 \mathrm{~kW})$ and $1 \mathrm{HP}(746$ $\mathrm{kW})$. The Induction motor with rated power $2 \mathrm{HP}$ was used to find characteristics of rotor and bearing damage. This induction motor was arranged with star connection $(\mathrm{Y})$, rated voltage $V_{t}=$ $380 \mathrm{~V}$ and rated current $I_{L}=3,44 \mathrm{~A}$. The induction motor for rotor and bearing damage were subjected to mechanical loading. This mechanical loading consisted of a synchronous generator coupled to motor, while the electrical load was a 100 W lamp. The synchronous generator was electrically loaded with three types of loads, that were no load, $600 \mathrm{~W}$ or $900 \mathrm{~W}$. The induction motor with rated power $1 \mathrm{HP}$ was used to find characteristics of stator damage. The stator winding of this motor had been re-twisted to reach short circuit condition. The connection of induction motor was connected with star connection $(\mathrm{Y})$, rated voltage $V_{t}=380 \mathrm{~V}$ and rated current $I_{L}=$ $2.1 \mathrm{~A}$.

\section{B. Induction Motor Damage Conditioning}

\section{1) Rotor damage}

The rotor portion was drilled with a certain amount, diameter, and depth for simula rotor fault was simulated by $\mathrm{n}$ known by broken rotor bar (1 was $8 \mathrm{BRB}$ with $3 \mathrm{~mm}$ depth at

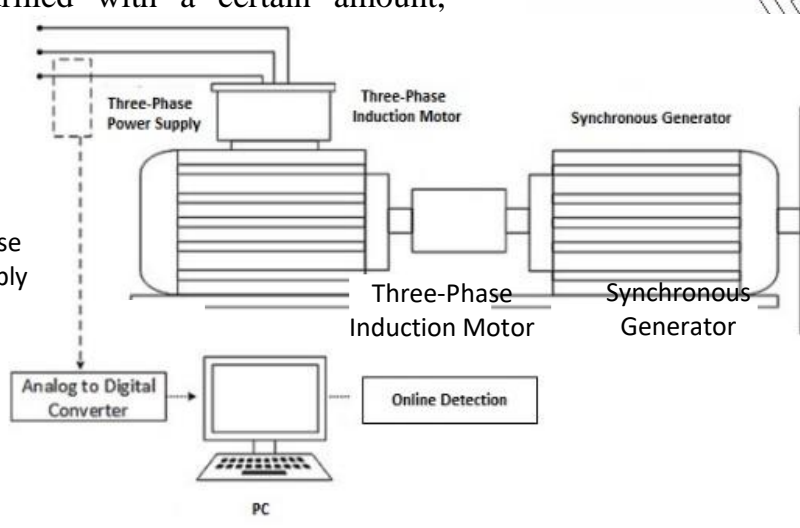

\section{2) Stator Damage}

One of the causes of stator damage to induction motor was short circuit in the stator winding. Fig. 3 showed that stator winding was re-twisted in the same way as normal condition and equipped with connector and external tab in phase $\mathrm{R}$ and $\mathrm{T}$ in order to simulate short circuit in stator windings of induction motor.

\section{3) Bearing Damage}

Condition of bearing fault on induction motor was provided by giving a hole defect. Fault reconstruction in this experiment was done by hollowing out the bearing. Fig. 4 showed the bearing hole with $5 \mathrm{~mm}$ depth and diameter.

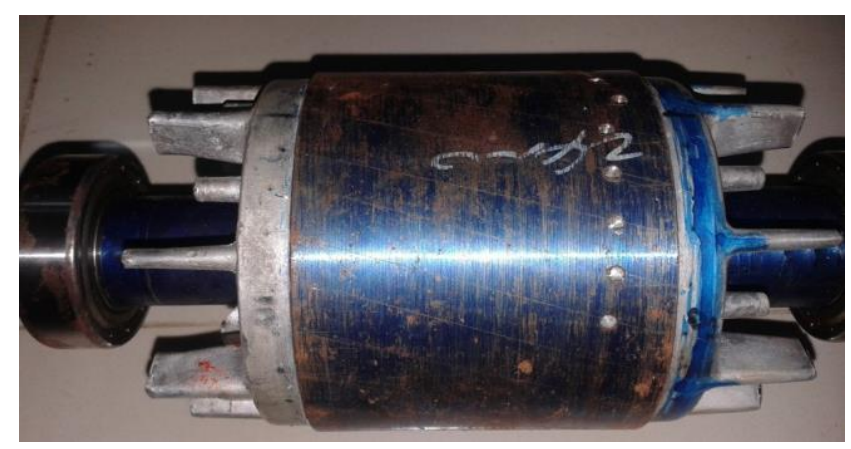

Fig. 2. Conditioning of rotor fault.

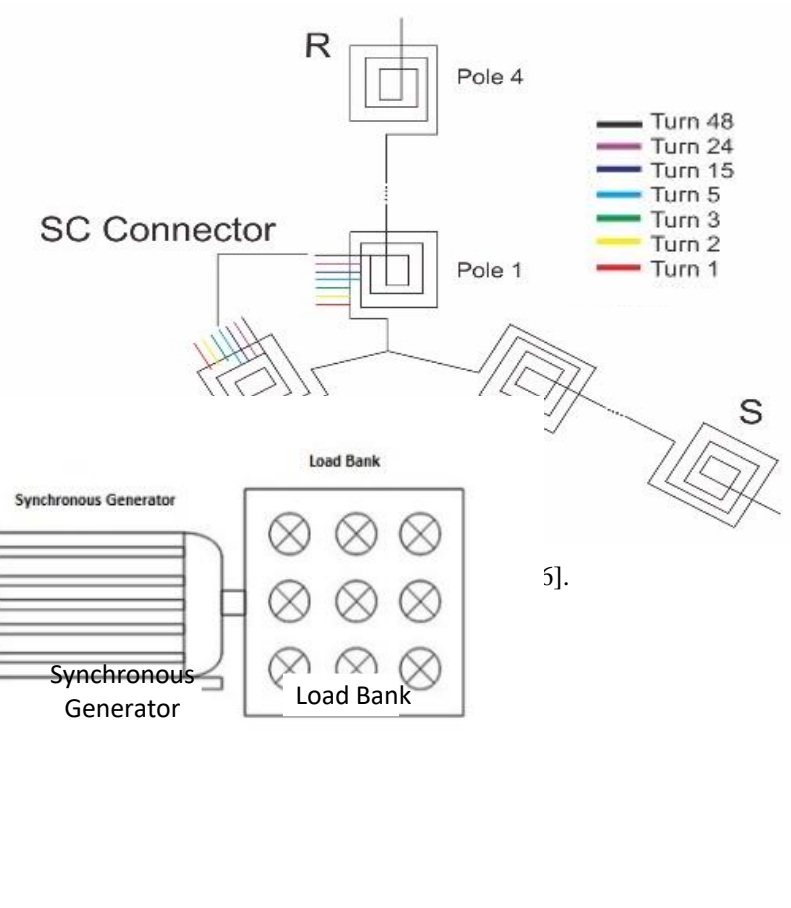

Fig. 1. Experimental scheme.

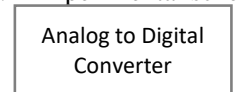




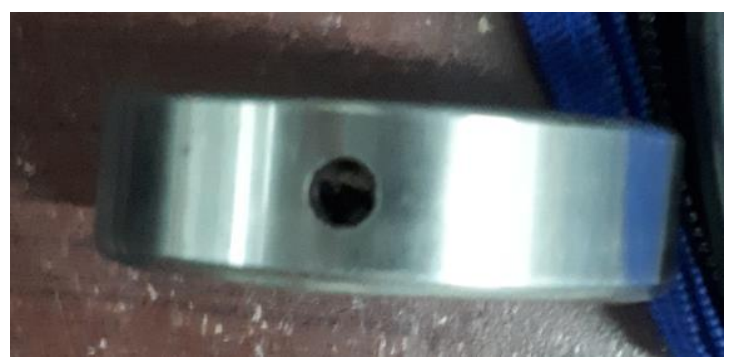

Fig. 4. Conditioning of bearing fault.

\section{Mechanical and Electrical Load}

A synchronous generator was employed as mechanical load, while a lamp as electrical load. The induction motor was coupled with a synchronous generator which was loaded with 100 Watt per lamp. The load variation was gradually given to induction motor during the experiment that was no-load (0 Watt), 6 lamps (600 Watt), and 9 lamps (900 Watt).

\section{Design of Detection Program}

Detection program was designed based on MCSA method in LabVIEW as seen in Fig. 5. It needed signal data when induction motor was in normal condition. These data would be reference to differ condition of induction motor between normal and fault. The reference data was frequency spectrum value in normal condition. If the obtained frequency was higher than its reference, so the value of obtained frequency would be shown in frequency indicator. The fault indicator would be on according to fault detection. The obtained frequency would be matched with frequency of faulty induction motor that has been determined using MCSA method as (1) - (4). The frequency in the detection program was set with $\pm 0.5 \mathrm{~Hz}$ tolerated value.

The input data for detection program was entered to find value of fault frequency and induction motor slip. The required data was fundamental frequency of power supply, total of pole, and rated rotor speed. The program would search for the slip value based on the input data.

The observed indicators were rotor indicator, stator indicator, bearing indicator, and detected frequency. Three first indicators may be on at the same time since the frequency of each fault has different threshold.

\section{E. Data Processing}

The data process was depicted on Fig. 6. LabVIEW was employed to process signal data. LabVIEW user interface program can detect three faults i.e., rotor fault, stator fault, and bearing fault. The input current was recorded by using current transformer connected to NI 9246. Then the current signal was displayed in LabVIEW user interface program graph. Furthermore, the recorded signal was transformed using fast fourier transform (FFT) that had been programmed in the block diagram of LabVIEW panel editor. In this block diagram, the signal as a result of FFT was compared with the reference frequency which had been calculated in the detection program according to $(1)-(4)$.

\section{RESULTS AND ANALYSIS}

\section{A. Characteristic Experiment Scheme for Each Fault}

Through this experiment the characteristics of frequency spectrum for each fault condition would be obtained. The obtained results would be main content in online detection program of induction motor faults. There were 90 data for each condition that was induction motor in normal condition, rotor fault, stator fault, bearing fault, and rotor-bearing fault. Table I was shown the experiment description.

\section{B. Normal Condition}

Fig. 7-9 showed the induction motor normal condition for different load, that was no load, $600 \mathrm{~W}$, and $900 \mathrm{~W}$, respectively.

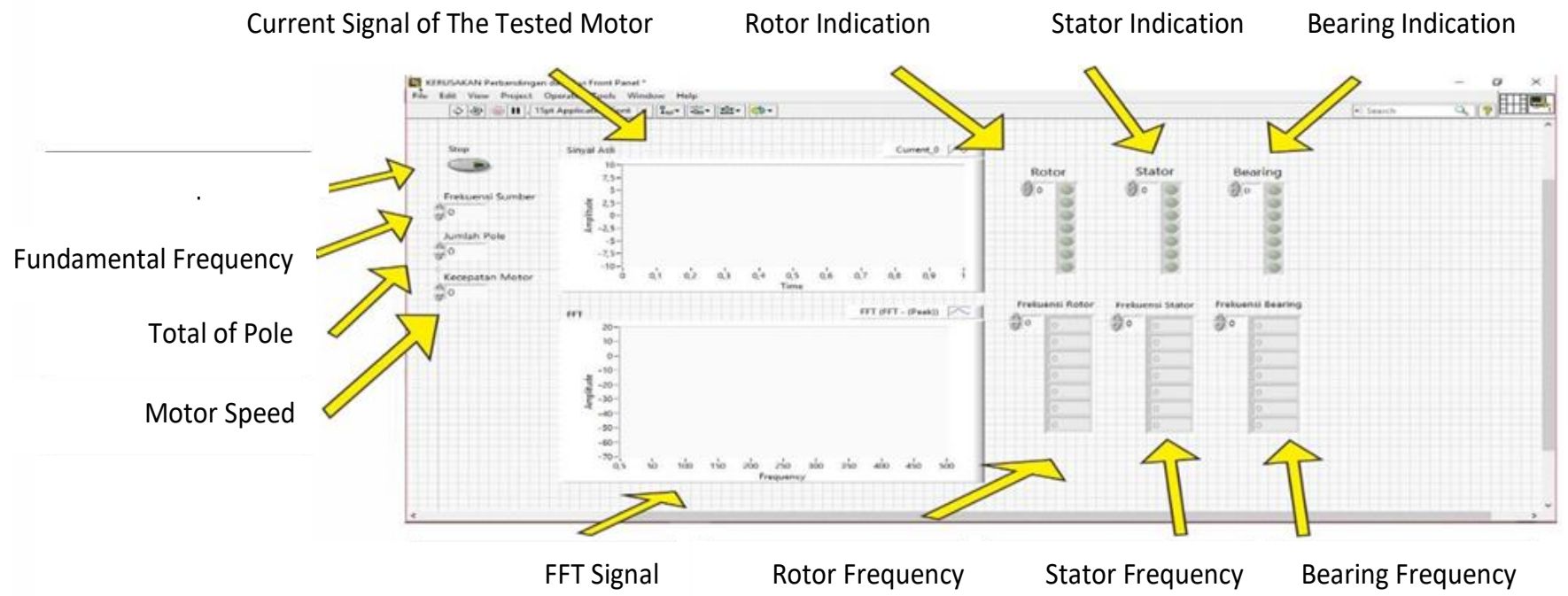

Fig. 5. Front panel on visual instrument LabVIEW. 
Current signal is recorded by NI 9246 and transfered to LabVIEW by personal computer.

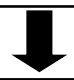

The recorded signal was transformed by FFT in LabVIEW.

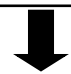

Detection program obtains frequency which has spectrum above normal condition.

Detection program compares the obtained frequency with reference frequency which is determined by MCSA

If the obtained frequency matches with reference frequency, fault indicator will be on.

Fig. 6. Flowchart of data processing.

TABLE I. CONFIGURATION OF EXPERIMENTAL SETUP.

\begin{tabular}{|c|c|c|c|}
\hline $\begin{array}{c}\text { Fault } \\
\text { Type }\end{array}$ & Parameter & $\begin{array}{c}\text { Experiment } \\
\text { for Each } \\
\text { Parameter }\end{array}$ & $\begin{array}{c}\text { Total of } \\
\text { Experiment }\end{array}$ \\
\hline Normal & $\begin{array}{c}\text { No load, 600 Watt, and } \\
\text { 900 Watt }\end{array}$ & 5 & 15 \\
\hline $\begin{array}{c}\text { 8 Broken } \\
\text { Rotor Bar }\end{array}$ & $\begin{array}{c}\text { No load, 600 Watt, and } \\
\text { 900 Watt }\end{array}$ & 5 & 15 \\
\hline & $\begin{array}{c}\text { Turn 1 - Turn 2 R Phase } \\
\text { Turn 1 - Turn 3 R Phase } \\
\text { Turn 1 - Turn 5 R Phase } \\
\text { Turn 1 - Turn 15 R } \\
\text { Phase }\end{array}$ & 5 & 30 \\
$\begin{array}{c}\text { Shorted } \\
\text { Turn R } \\
\text { Phase }\end{array}$ & $\begin{array}{c}\text { Turn 1 - Turn 24 R } \\
\text { Phase } \\
\text { Purn 1 - Turn 48 R } \\
\text { Phase }\end{array}$ & 5 & 15 \\
\hline $\begin{array}{c}\text { Outer } \\
\text { Race } \\
\text { Bearing } \\
\text { Fault }\end{array}$ & $\begin{array}{c}\text { No Load, 600 Watt, and } \\
900 \text { Watt }\end{array}$ & 5 & 15 \\
\hline $\begin{array}{c}\text { Broken } \\
\text { Rotor Bar } \\
\text { and Outer } \\
\text { Race } \\
\text { Bearing } \\
\text { Fault }\end{array}$ & $\begin{array}{c}\text { No Load, 600 Watt, and } \\
900 \text { Watt }\end{array}$ & 5 & \\
\hline \multicolumn{2}{|c|}{\begin{tabular}{l} 
Total \\
\hline
\end{tabular}} & 5 & \\
\hline
\end{tabular}

\section{Rotor Fault Detection}

The experiment of rotor fault condition was conducted by using damaged rotor rod. It aimed to obtain the characteristics of rotor fault on induction motor. The experiments were also performed by adding load variations.

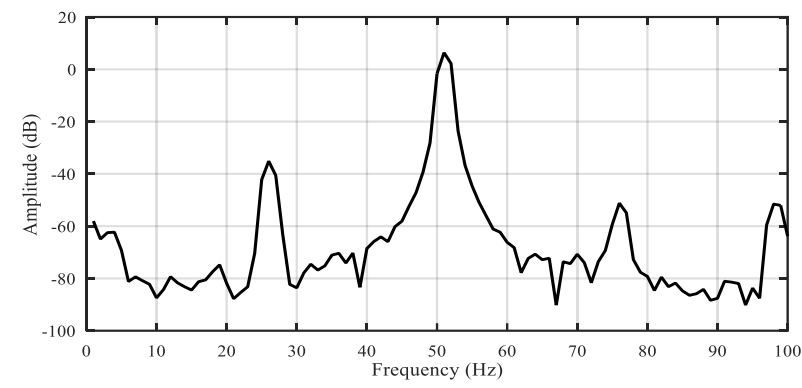

Fig. 7. Frequency spectrum during normal condition without load.

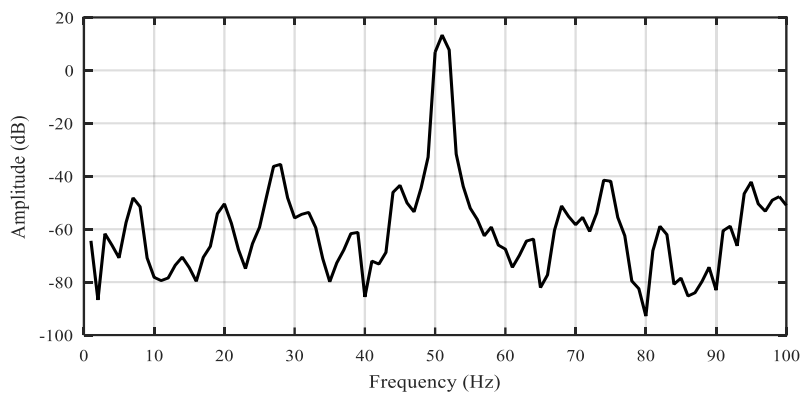

Fig. 8. Frequency spectrum during normal condition with 600 Watt.

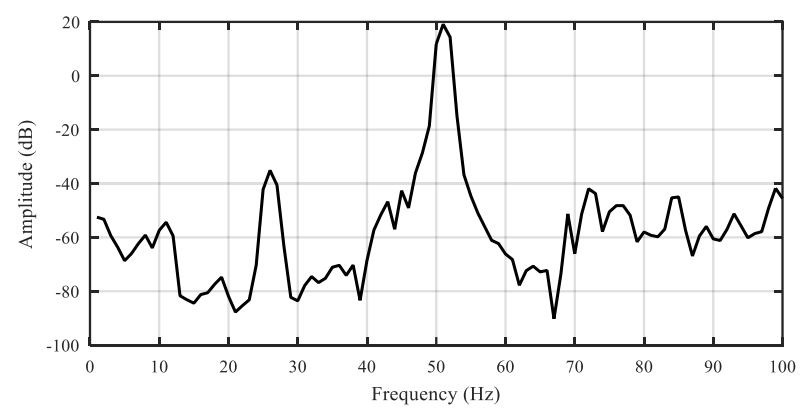

Fig. 9. Frequency spectrum during normal condition with 900 Watt.

The detection program would obtain frequency value which was then shown in the graph. The obtained frequency value had spectrum more than the reference frequency. The detection program was designed to calculate the frequency value indicating rotor fault frequency corresponding to (1). The program would select the data that matched with the determined frequency value. If the obtained frequency was same with the reference frequency value, so the indicator would light up as seen in Fig. 10.

Fig. 11-13 showed the comparison of signal between normal condition and rotor fault. The rotor fault frequency amplitude had higher peak than the normal condition frequency amplitude. Table II showed frequency data of rotor fault for different motor loading

\section{Stator Fault Detection}

The detection program was designed to calculate the frequency value indicating rotor fault frequency corresponding to (2). The program would select data that matched with the designed frequency value. If the obtained frequency was same 
with the reference frequency value, so the indicator would light up.
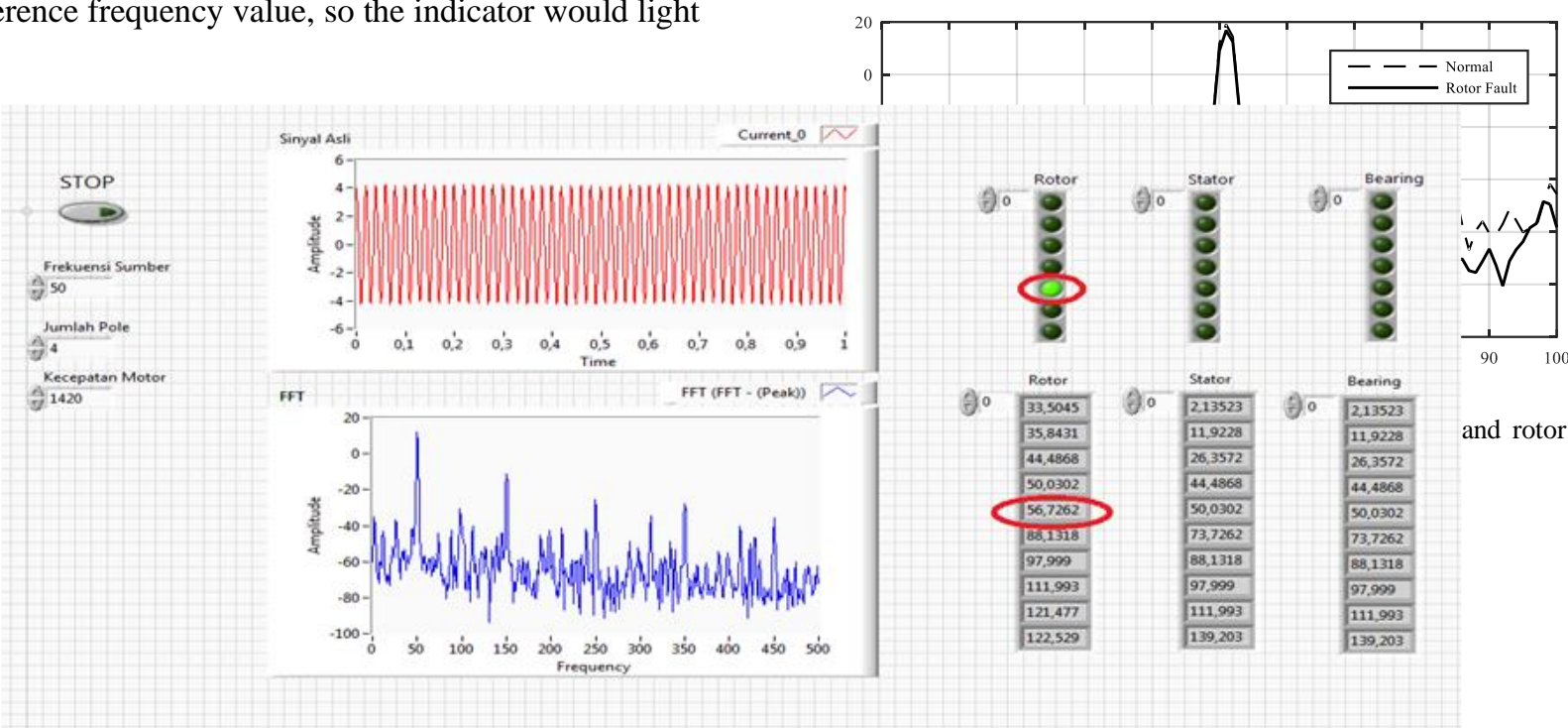

Fig. 10. Display of program during online detection process.

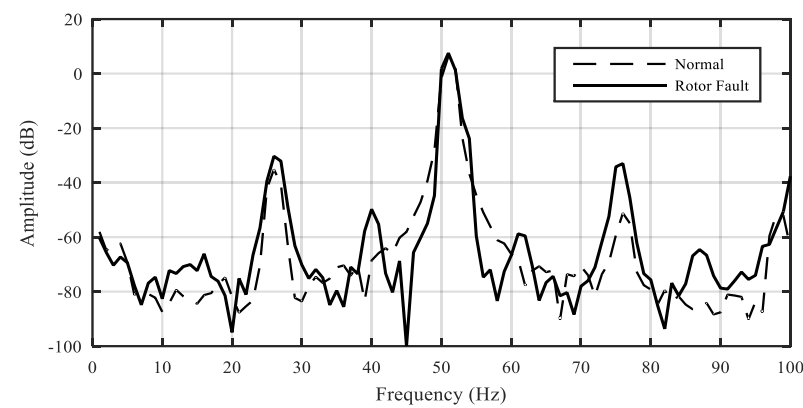

Fig. 11. Frequency spectrum during normal condition and roto fault without load.

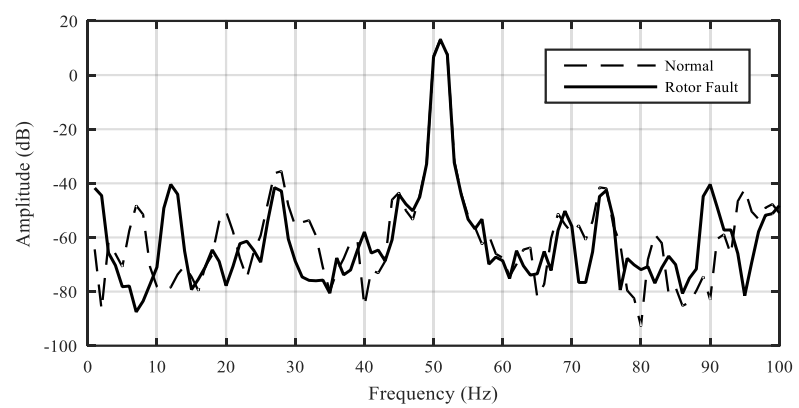

Fig. 12. Frequency spectrum during normal condition and rotor fault with 600 Watt.
Fig. 14-19 showed the comparison of signal between normal condition and short circuit windings, while their values were seen in Table III. The short-circuit winding frequency amplitude had higher peak than normal condition.

TABLE II. FREQUENCY DATA OF ROTOR FAULT FOR DIFFERENT MOTOR LOADING

\begin{tabular}{|c|c|c|c|c|c|}
\hline $\begin{array}{l}\text { Fault } \\
\text { Type }\end{array}$ & $\begin{array}{l}\text { Load } \\
\text { Type }\end{array}$ & Slip & $\begin{array}{c}\text { Experiment } \\
\text { to- }\end{array}$ & $\begin{array}{c}\text { Reference } \\
\text { Frequency } \\
(\mathbf{H z})\end{array}$ & $\begin{array}{c}\text { Detected } \\
\text { Frequency } \\
(\mathbf{H z}) \\
\end{array}$ \\
\hline \multirow{14}{*}{$\begin{array}{c}8 \text { Broken } \\
\text { Bar } \\
\text { Rotor }\end{array}$} & \multirow{5}{*}{ No Load } & \multirow{5}{*}{0.02} & 1 & \multirow{5}{*}{52} & 52.14 \\
\hline & & & 2 & & 51.91 \\
\hline & & & 3 & & 52.41 \\
\hline & & & 4 & & 52.23 \\
\hline & & & 5 & & 51.81 \\
\hline & \multirow{5}{*}{600 Watt } & \multirow{5}{*}{0.054} & 1 & \multirow{5}{*}{55.3} & 55.41 \\
\hline & & & 2 & & 55.25 \\
\hline & & & 3 & & 55.71 \\
\hline & & & 4 & & 55.14 \\
\hline & & & 5 & & 55.31 \\
\hline & \multirow{4}{*}{900 Watt } & \multirow{4}{*}{0.11} & 1 & \multirow{4}{*}{61} & 61.13 \\
\hline & & & 2 & & 60.99 \\
\hline & & & 3 & & 61.02 \\
\hline & & & 4 & & 60.95 \\
\hline
\end{tabular}




\begin{tabular}{|l|l|l|l|l|l|}
\hline & & & 5 & & 61.24 \\
\hline
\end{tabular}

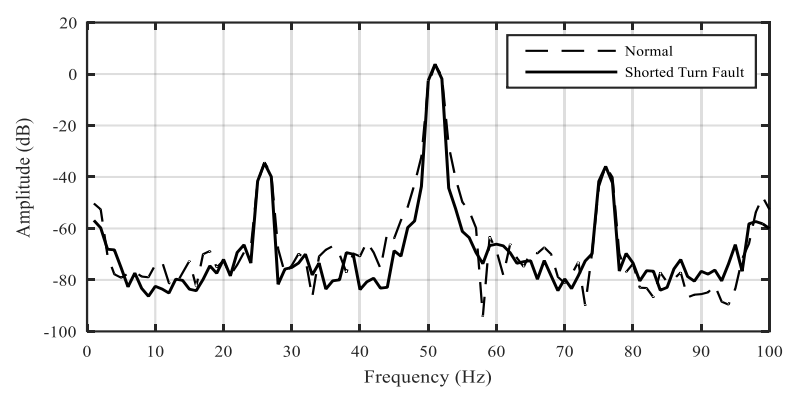

Fig. 14. Frequency spectrum during normal condition and short circuit turn 1 - turn 2 in $\mathrm{R}$ phase.

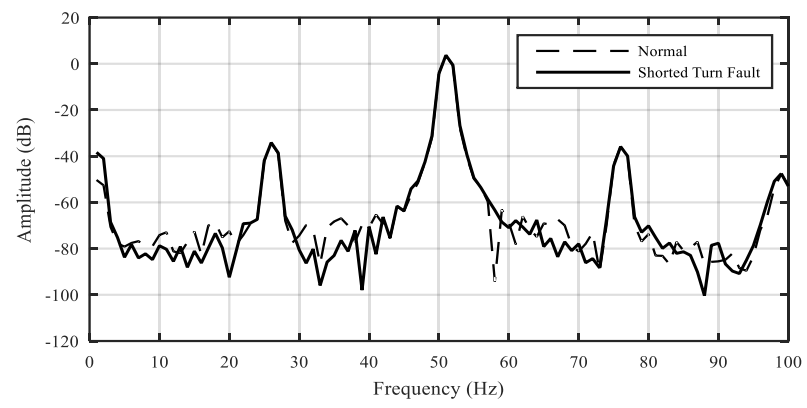

Fig. 15. Frequency spectrum during normal condition and shor circuit turn 1 - turn 3 in $R$ phase.

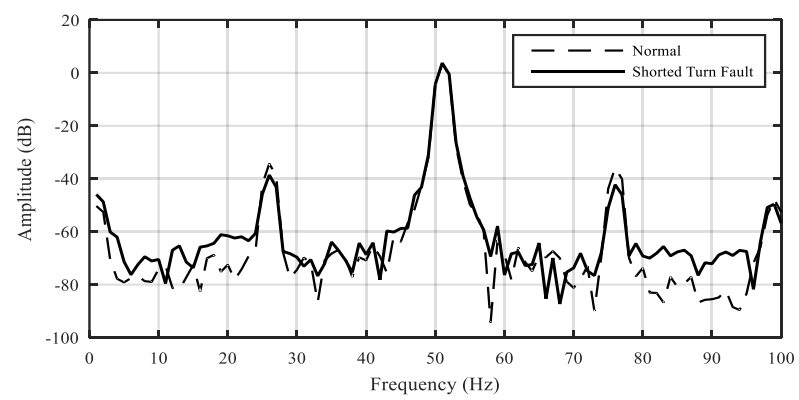

Fig. 16. Frequency spectrum during normal condition and short circuit turn 1 - turn 5 in $\mathrm{R}$ phase.

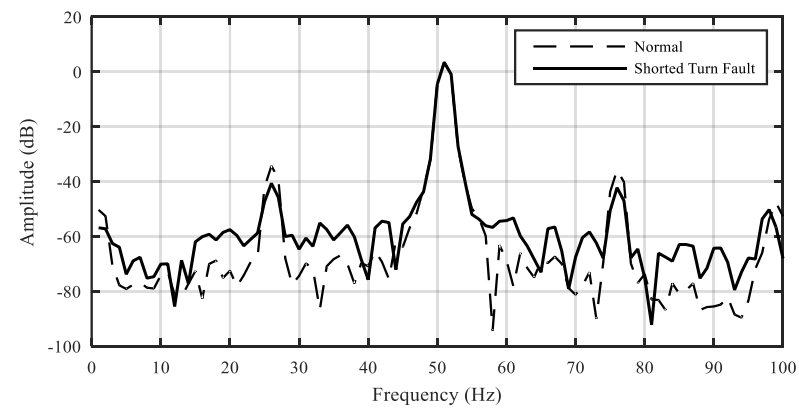

Fig. 17. Frequency spectrum during normal condition and short circuit turn 1 - turn 15 in $\mathrm{R}$ phase.

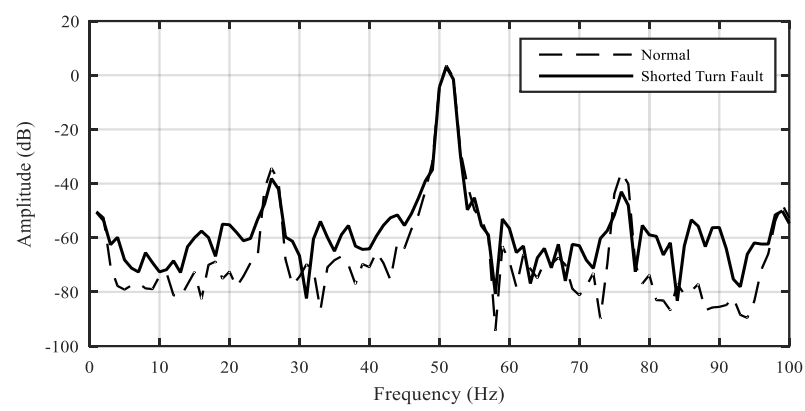

Fig. 18. Frequency spectrum during normal condition and short circuit turn 1 - turn 24 in $\mathrm{R}$ phase.

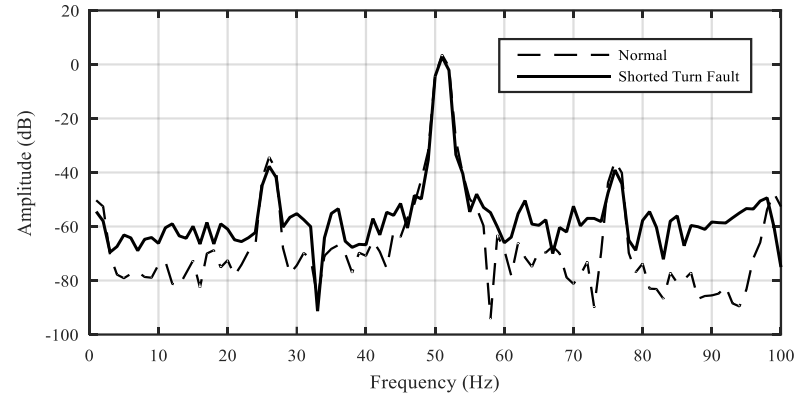

Fig. 19. Frequency spectrum during normal condition and short circuit turn 1 - turn 48 in R phase.

TABLE III. FREQUENCY DATA OF STATOR FAULT FOR DIFFERENT SHORT CIRCUIT CONDITION

\begin{tabular}{|c|c|c|c|c|c|}
\hline $\begin{array}{l}\text { Fault } \\
\text { Type }\end{array}$ & $\begin{array}{c}\text { Short } \\
\text { Circuit } \\
\text { Type }\end{array}$ & Slip & $\begin{array}{c}\text { Experiment } \\
\text { to- }\end{array}$ & $\begin{array}{c}\text { Reference } \\
\text { Frequency } \\
(\mathbf{H z})\end{array}$ & $\begin{array}{c}\text { Detected } \\
\text { Frequency } \\
(\mathbf{H z})\end{array}$ \\
\hline \multirow{22}{*}{$\begin{array}{c}\text { Shorted } \\
\text { Turn R } \\
\text { Phase }\end{array}$} & \multirow{5}{*}{$\begin{array}{c}\text { Turn } 1- \\
\text { Turn } 2 \text { R } \\
\text { Phase }\end{array}$} & \multirow{5}{*}{0.013} & 1 & \multirow{5}{*}{87.01} & \multirow{5}{*}{ Undetected } \\
\hline & & & 2 & & \\
\hline & & & 3 & & \\
\hline & & & 4 & & \\
\hline & & & 5 & & \\
\hline & \multirow{5}{*}{$\begin{array}{c}\text { Turn } 1- \\
\text { Turn } 3 \text { R } \\
\text { Phase }\end{array}$} & \multirow{5}{*}{0.013} & 1 & \multirow{5}{*}{87.01} & \multirow{5}{*}{ Undetected } \\
\hline & & & 2 & & \\
\hline & & & 3 & & \\
\hline & & & 4 & & \\
\hline & & & 5 & & \\
\hline & \multirow{5}{*}{$\begin{array}{c}\text { Turn } 1- \\
\text { Turn } 5 \mathrm{R} \\
\text { Phase }\end{array}$} & \multirow{5}{*}{0.013} & 1 & \multirow{5}{*}{87.01} & \multirow{5}{*}{ Undetected } \\
\hline & & & 2 & & \\
\hline & & & 3 & & \\
\hline & & & 4 & & \\
\hline & & & 5 & & \\
\hline & \multirow{5}{*}{$\begin{array}{l}\text { Turn } 1- \\
\text { Turn } 15 \\
\text { R Phase }\end{array}$} & \multirow{5}{*}{0.013} & 1 & \multirow{5}{*}{87.01} & 87.12 \\
\hline & & & 2 & & 86.91 \\
\hline & & & 3 & & 86.65 \\
\hline & & & 4 & & 86.97 \\
\hline & & & 5 & & 87.04 \\
\hline & \multirow{2}{*}{$\begin{array}{l}\text { Turn } 1- \\
\text { Turn } 24\end{array}$} & \multirow{2}{*}{0.013} & 1 & \multirow{2}{*}{87.01} & 87.04 \\
\hline & & & 2 & & 87.02 \\
\hline
\end{tabular}




\begin{tabular}{|c|c|c|c|c|}
\hline \multirow[t]{3}{*}{ R Phase } & & 3 & & 86.91 \\
\hline & & 4 & & 86.95 \\
\hline & & 5 & & 87.09 \\
\hline \multirow{5}{*}{$\begin{array}{l}\text { Turn 1- } \\
\text { Turn } 48 \\
\text { R Phase }\end{array}$} & \multirow{5}{*}{0.013} & 1 & \multirow{5}{*}{87.01} & 87.02 \\
\hline & & 2 & & 87.04 \\
\hline & & 3 & & 86.93 \\
\hline & & 4 & & 86.91 \\
\hline & & 5 & & 86.95 \\
\hline
\end{tabular}

\section{E. Bearing Fault Detection}

The experiment of bearing fault condition was conducted by using damaged bearing. It aimed to obtain the characteristics of bearing fault. The experiments were also performed by adding load variations.

The detection program was designed to calculate the frequency value indicating rotor damaged frequency corresponding to (3) - (4). The program would select data that matched with the designed frequency value. If the obtained frequency was same with the reference frequency value, so the indicator would light up.

Fig. 20-22 showed the comparison of signal between normal condition and bearing fault, whereas their values were shown in Table IV. The bearing fault frequency amplitude had higher peak than normal condition frequency amplitude.

\section{F. Combination of Rotor and Bearing Fault}

Fig. 23-25 showed comparison signal between normal condition and rotor-bearing fault combination, while their frequency values was shown in Table V. The rotor-bearing fault frequency amplitude had higher peak than the normal condition frequency amplitude.

TABLE IV. FREQUENCY DATA OF BEARING FAULT FOR DIFFERENT MOTOR LOADING

\begin{tabular}{|c|c|c|c|c|c|}
\hline $\begin{array}{l}\text { Fault } \\
\text { Type }\end{array}$ & $\begin{array}{c}\text { Loading } \\
\text { Type }\end{array}$ & Slip & $\begin{array}{c}\text { Experiment } \\
\text { to- }\end{array}$ & $\begin{array}{c}\text { Reference } \\
\text { Frequency } \\
\quad(\mathbf{H z})\end{array}$ & $\begin{array}{c}\text { Detected } \\
\text { Frequency } \\
\text { (Hz) }\end{array}$ \\
\hline \multirow{14}{*}{$\begin{array}{l}\text { Outer } \\
\text { Race } \\
\text { Bearing } \\
\text { Fault }\end{array}$} & \multirow{5}{*}{ No Load } & \multirow{5}{*}{0.02} & 1 & \multirow{5}{*}{30.4} & 30.44 \\
\hline & & & 2 & & 30.41 \\
\hline & & & 3 & & 30.53 \\
\hline & & & 4 & & 30.34 \\
\hline & & & 5 & & 30.45 \\
\hline & \multirow{5}{*}{600 Watt } & \multirow{5}{*}{0.097} & 1 & \multirow{5}{*}{31.94} & 32.21 \\
\hline & & & 2 & & 31.74 \\
\hline & & & 3 & & 32.05 \\
\hline & & & 4 & & 32.14 \\
\hline & & & 5 & & 31.8 \\
\hline & \multirow{4}{*}{900 Watt } & \multirow{4}{*}{0.133} & 1 & \multirow{4}{*}{32.66} & 32.97 \\
\hline & & & 2 & & 32.81 \\
\hline & & & 3 & & 32.51 \\
\hline & & & 4 & & 32.64 \\
\hline
\end{tabular}

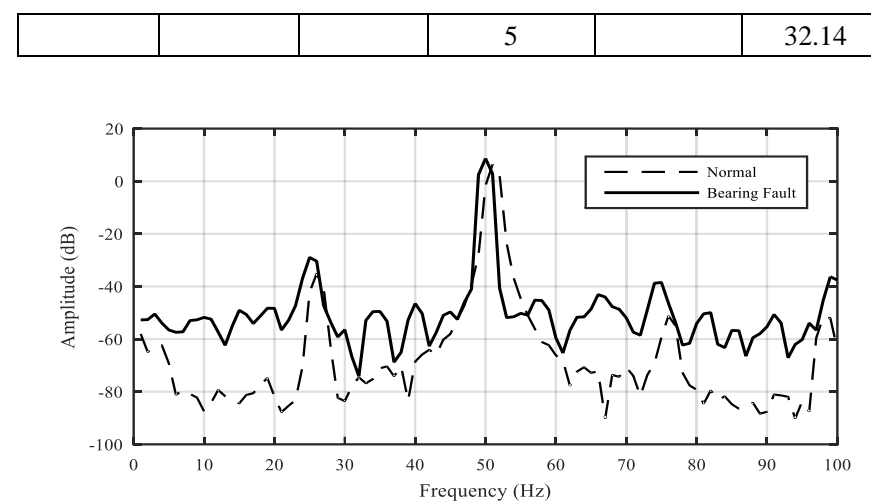

Fig. 20. Frequency spectrum during normal condition and bearing fault without load.

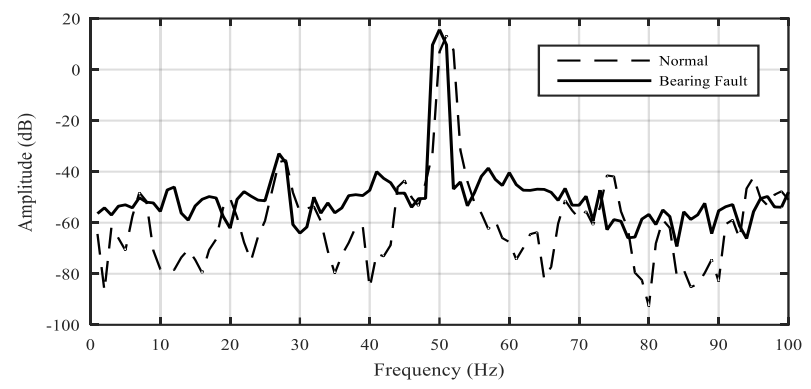

Fig. 21. Frequency spectrum during normal condition and bearing fault with 600 Watt.

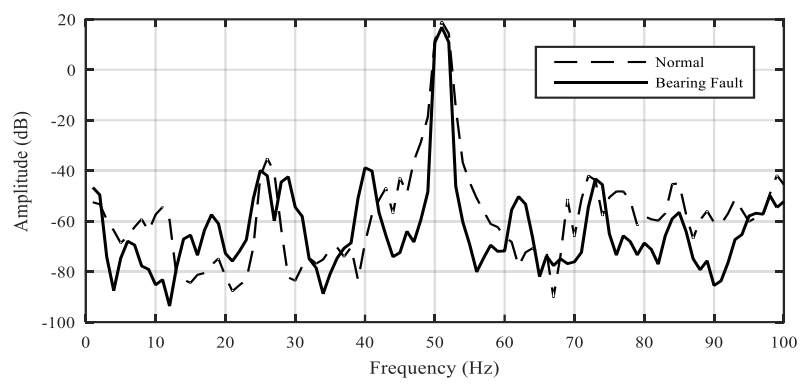

Fig. 22. Frequency spectrum during normal condition and bearing fault with 900 Watt.

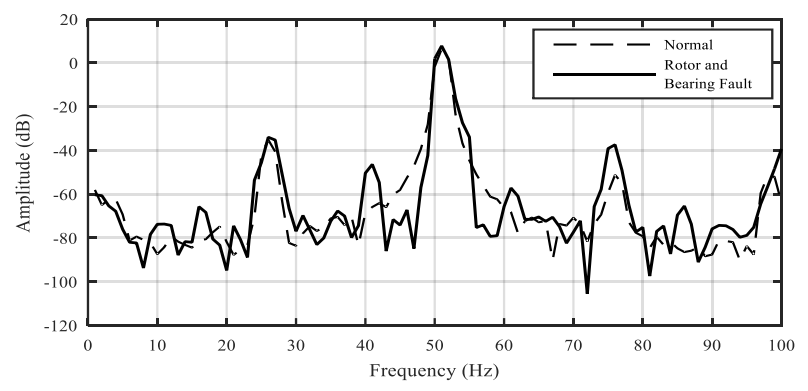

Fig. 23. Frequency spectrum during normal condition and bearingrotor fault without load. 


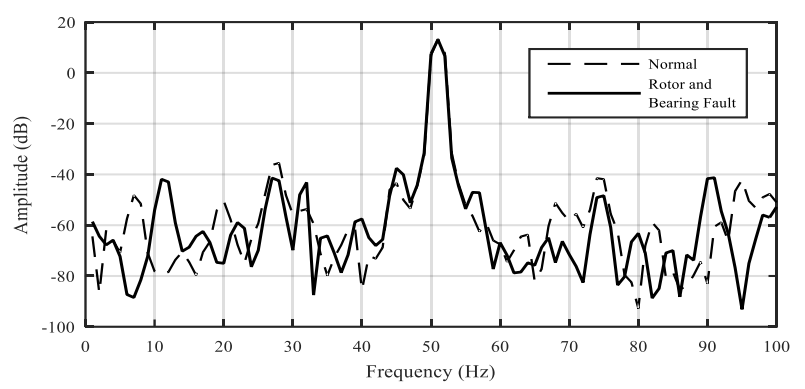

Fig. 24. Frequency spectrum during normal condition and bearingrotor fault with 600 Watt.

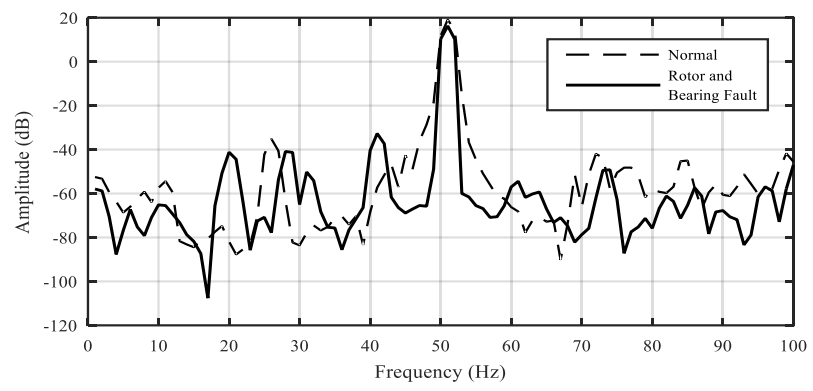

Fig. 25. Frequency spectrum during normal condition and bearingrotor fault with 900 Watt.

TABLE V. FREQUENCY DATA OF ROTOR FAULT AND BEARING FOR DIFFERENT MOTOR LOADING

\begin{tabular}{|c|c|c|c|c|c|c|c|}
\hline \multirow[t]{2}{*}{$\begin{array}{l}\text { Fault } \\
\text { Type }\end{array}$} & \multirow[t]{2}{*}{$\begin{array}{c}\text { Loading } \\
\text { Type }\end{array}$} & \multirow[t]{2}{*}{ Slip } & \multirow[t]{2}{*}{$\begin{array}{c}\text { Experiment } \\
\text { to- }\end{array}$} & \multicolumn{2}{|c|}{$\begin{array}{c}\text { Reference } \\
\text { Frequency } \\
(\mathrm{Hz})\end{array}$} & \multicolumn{2}{|c|}{$\begin{array}{c}\text { Detected } \\
\text { Frequency }(\mathrm{Hz})\end{array}$} \\
\hline & & & & Rotor & Bearing & Rotor & Bearing \\
\hline \multirow{15}{*}{\begin{tabular}{|c|}
8 \\
Broken \\
Bar \\
Rotor \\
and \\
Outer \\
Race \\
Bearing \\
Fault
\end{tabular}} & \multirow{5}{*}{ No Load } & \multirow{5}{*}{0.02} & 1 & \multirow{5}{*}{52} & \multirow{5}{*}{30.4} & 52.10 & 29.92 \\
\hline & & & 2 & & & 51.83 & 30.25 \\
\hline & & & 3 & & & 52.14 & 30.31 \\
\hline & & & 4 & & & 51.41 & 30.52 \\
\hline & & & 5 & & & 52.32 & 30.01 \\
\hline & \multirow{5}{*}{600 Watt } & \multirow{5}{*}{0.067} & 1 & \multirow{5}{*}{56.67} & \multirow{5}{*}{31.34} & 56.78 & 31.21 \\
\hline & & & 2 & & & 56.71 & 31.32 \\
\hline & & & 3 & & & 56.54 & 31.21 \\
\hline & & & 4 & & & 56.68 & 31.41 \\
\hline & & & 5 & & & 56.81 & 31.32 \\
\hline & \multirow{5}{*}{900 Watt } & \multirow{5}{*}{0.11} & 1 & \multirow{5}{*}{60} & \multirow{5}{*}{31.94} & 59.86 & 31.84 \\
\hline & & & 2 & & & 59.79 & 31.78 \\
\hline & & & 3 & & & 59.87 & 31.96 \\
\hline & & & 4 & & & 59.76 & 31.80 \\
\hline & & & 5 & & & 59.81 & 31.75 \\
\hline
\end{tabular}

\section{G. Accuracy of Detection Program for All Experiment}

Table VI showed that the accuracy for detection program reached $90 \%$. The detection accuracy rate was $100 \%$ for rotor fault condition, bearing fault, and rotor-bearing fault combination. For a case of stator fault condition, the detection accuracy rate was only $50 \%$ because the level of program sensitivity had not been perfect.
TABLE VI. ACCURACY OF DETECTION PROGRAM.

\begin{tabular}{|c|c|c|c|c|}
\hline $\begin{array}{c}\text { Fault } \\
\text { Type }\end{array}$ & Loading Type & $\begin{array}{c}\text { Experiment } \\
\text { for Each } \\
\text { Parameter }\end{array}$ & $\begin{array}{c}\text { Experiment } \\
\text { to- }\end{array}$ & $\begin{array}{c}\text { Accuracy } \\
\text { (\%) }\end{array}$ \\
\hline Normal & $\begin{array}{c}\text { No Load, 600 Watt, and } \\
\text { 900 Watt }\end{array}$ & 5 & 15 & 100 \\
\hline $\begin{array}{c}\text { 8 Broken } \\
\text { Rotor Bar }\end{array}$ & $\begin{array}{c}\text { No Load, 600 Watt, and } \\
\text { 900 Watt }\end{array}$ & 5 & 15 & 100 \\
\hline $\begin{array}{c}\text { Turn 1 - Turn 2 R Phase } \\
\text { Turn 1 - Turn 3 R Phase } \\
\text { Turn 1 - Turn 5 R Phase } \\
\text { Turn 1 - Turn 15 R } \\
\text { Phase } \\
\text { Turn }\end{array}$ & $\begin{array}{c}\text { Phase R } \\
\text { Turn 1 Turn 24 R } \\
\text { Phase } \\
\text { Turn 1 Turn 48 R } \\
\text { Phase }\end{array}$ & 5 & 30 & 50 \\
\hline $\begin{array}{c}\text { Outer } \\
\text { Race } \\
\text { Bearing } \\
\text { Fault }\end{array}$ & $\begin{array}{c}\text { No Load, 600 Watt, and } \\
900 \text { Watt }\end{array}$ & 5 & 15 & 100 \\
\hline $\begin{array}{c}\text { Broken } \\
\text { Rotor Bar } \\
\text { and Outer } \\
\text { Race } \\
\text { Bearing } \\
\text { Fault }\end{array}$ & $\begin{array}{c}\text { No Load, 600 Watt, and } \\
900 \text { Watt }\end{array}$ & 5 & 15 & 100 \\
\hline & Total & & 90 \\
\hline
\end{tabular}

\section{CONCLUSION}

The designed MCSA based on LabVIEW for online detection of induction motor damages was able to detect the given faults, such as stator fault, rotor fault, and bearing fault. There was harmonics frequency which indicated certain fault on induction motor. The frequency spectrum was different for each faults. If the detected frequency matched with the frequency which had been determined using MCSA method, the fault indicator of detection program would be on. The detection program had also been tested and its accuracy reached $90 \%$.

\section{REFERENCES}

[1] M.J. Castelli, J.P. Fossati, M.T. Andrade "New Methodology to Faults Detection in Induction Motor ia MCSA", IEEE/PES Transmission and Distribution Conference and Exposition : Latin America, 2008

[2] S. Grubic, J. M. Aller, and T. G. Habetler, "A Survey on Testing and Monitoring Methods for Stator Insulation Systems of Low-Voltage Induction Machines Focusing on Turn Insulation Problems", IEEE Transactions on Dielectrics and Electrical Insulation, vol. 55, no. 12, Dec. 2008.

[3] Jee-Hoon Jung, Jong-Jae Lee, Bong-Hwan Kwon "Online Diagnosis of Induction Motors Using MCSA", IEEE Transactions on Industrial Electronics, Vol. 53, No. 6, Desember 2006

[4] Rangga Chilaka, Chandel Ashwani Kumar "Advanced Tool Based Condition Monitoring by Using LabVIEW A Review", IEEE UP Section Conference on Electrical Computer and Electronics (UPCON), 2015

[5] Mehala Neelam, Dahiya Ratna,"Motor Current Signature Analysis and its Applications in Induction Motor Fault Diagnosis", International Journal of System Applications, Engineering and Development, Volume 2 Issue 1, India, 2007.

[6] Succliftom Tegar "Detection of Insulation Fault Phase-to-Phase on Induction Motor Using Surge Test (In Indonesian)", Electrical Engineering Department, Institut Teknologi Sepuluh Nopember, 2015. 